\title{
The physiological status of Douglas fir seedlings and the field performance of freshly lifted and cold stored stock
}

\author{
Conor O’Reilly ${ }^{\mathrm{a}^{*}, N^{\prime}}$ Nick McCarthy ${ }^{\mathrm{b}}$, Michael Keane ${ }^{\mathrm{c}}$, Charles P. Harper ${ }^{\mathrm{a}}$, John J. Gardiner ${ }^{\mathrm{a}}$ \\ aDepartment of Crop Science, Horticulture and Forestry, Faculty of Agriculture, University College Dublin, \\ Belfield, Dublin 4, Ireland \\ bWaterford Institute of Technology, Waterford, Ireland \\ 'Research and Development Division, CoillteTeo, Newtownmountkennedy, Co. Wicklow, Ireland
}

(Received 17 December 1997; accepted 2 March 1999)

\begin{abstract}
The physiological status of Douglas fir seedlings in Ireland was followed from October to April each year from 1991-1995 and examined in relation to field performance in a farm-field trial established concurrently with the physiology work. A precise cold hardiness pattern was defined: the seedlings were less cold hardy in 1994/1995 than in other years, but the period of highest cold hardiness was from November to February each year. The roots of the seedlings were mitotically active throughout the winter in some years. The best time to plant freshly lifted stock was from November to December/January. Following cold storage until June, field performance was acceptable for seedlings lifted to the store from December/ January to February. (ㅇ Inra/Elsevier,
\end{abstract} Paris.)

plant quality / plant handling / cold hardiness / mitotic index / cold storage / Pseudotsuga menziesii

Résumé - État physiologique et performance en plantation de plants de douglas frais ou conservés au froid. L'état physiologique de semis de douglas en Irlande a été suivi d'octobre à avril, chaque année de 1991 à 1995 . Il a été mis en relation avec la performance des plants après plantation sur terre agricole. L'évolution de l'endurcissement au froid des semis a pu être défini: les semis étaient moins résistants au froid en 1994/1995 que les autres années, mais la période de résistance maximale au froid allait toujours de novembre à debut février. Les racines des semis ont eu une activité mitotique durant l'hiver, certaines années. L'époque optimale de plantation des plants frais allait de novembre à décembre-janvier. Après stockage au froid jusqu'en juin, la performance des plants était correcte lorsque l'arrachage avait été effectué de décembre-janvier à février. (ㅇ) Inra/Elsevier, Paris.)

qualité des plants / manutention des plants / résistance au froid / indice mitotique / stockage au froid / Pseudostuga menziesii

\section{Introduction}

The use of freshly lifted bare-root seedlings between November and March is still the most common practice followed in the planting programme in Ireland. The planting stock is usually sufficiently dormant at this time to resist the stresses of lifting and handling. This practice has been relatively successful with many species (espe- cially Picea sitchensis (Bong.) Carr.), but low survival and/or poor growth following planting was revealed to be a common problem with Douglas fir (Pseudotsuga menziesii (Mirb.) Franco).

It has long been suspected that variation in the physiological quality of planting stock contributed to these establishment problems. The annual change in dormancy state, stress resistance levels and root growth potential

\footnotetext{
* Correspondence and reprints

conor.oreilly@ucd.ie
} 
have been shown to be key determinants of planting stock quality in Douglas fir and other species [21, 24]. Results from studies carried out in Britain have indicated that Douglas fir planting stock is highly sensitive to the stresses of lifting, handling and cold storing $[4,19,32]$.

Douglas fir is native to north-western North America and it has evolved in areas where the climate is relatively mild, but summer droughts are common. For this reason, it is thought that dormancy development in Douglas fir responds to specific environmental cues, such as drought stress in late summer followed by chilling in autumn and winter [28]. However, there is a widespread belief in forestry in Ireland that Douglas fir does not become fully dormant in the winter. Ireland rarely experiences droughts and winters are often very mild. Thus, the annual cycle of dormancy development in this species may differ in Ireland from that reported elsewhere. Therefore, the first objective of this study was to describe the physiological status of Douglas fir seedlings during the period spanning the lifting season. While bud dormancy stage or days to bud break [12] was not estimated in this study, the dormancy status and stress resistance levels of the seedlings were assessed indirectly using physiological parameters such as mitotic index and cold hardiness levels. The performance of seedlings in a farm-field trial established concurrently with the physiology work was evaluated to determine if there was an association between physiological status and performance.

Although most forests in Ireland are established by using freshly lifted stock, an increasing proportion (10-20\%) of seedlings is now cold stored. As mentioned above, some results from the UK indicate that Douglas fir is highly sensitive to cold storage, perhaps not tolerating more than $2-3$ months of storage without significant deterioration $[4,19,32]$. The most likely reason for the poor field performance of cold stored stock may be because this species does not become sufficiently dormant in the British climate [19]. The second objective of this study was to evaluate the potential for cold storing Douglas fir in Ireland.

\section{Materials and methods}

\subsection{Plant material and sampling}

Douglas fir transplants $(2+1)$ grown in Ballintemple Nursery, Co. Carlow (lat. $52^{\circ} 44^{\prime} \mathrm{N}$, long. $6^{\circ} 42^{\prime} \mathrm{W}, 100$ m elevation) were sampled at 2-4 week intervals from September/October until April in 1991/1992, 1992/1993, $1993 / 1994$ and 1994/1995. The seedlings were of a Washington provenance each year (seed zone identities and elevations: 1991/1992: 042, $450 \mathrm{~m} ; 1992 / 1993$, 1994/1995: 041, $300 \mathrm{~m}$; and 1993/1994: 412, $600 \mathrm{~m}$ ); the exact location of each provenance is not known. The seedlings were lined out in July/August of the year prior to lifting. In each year, sections or whole beds of seedlings were chosen from the commercial crop and set aside for study. The seedlings received identical treatments to those used operationally in the planting programme. The mean heights (and standard errors) of the transplants were $66(1.3), 62(0.9), 57(1.2)$ and 65 (1.5) $\mathrm{cm}$, and the mean root collar diameters were 10 (0.3), $9(0.2), 9(0.3)$ and $11(0.4) \mathrm{mm}$ in 1991/1992, $1992 / 1993,1993 / 1994$ and $1994 / 1995$, respectively. These values were based upon measurements of 60 seedlings each year.

The soil in this nursery is a sandy loam of about $\mathrm{pH}$ 5.7 , having an organic matter content of $8-12 \%$, and sand, silt and clay fractions of 66,19 and $15 \%$, respectively. The cultural practices used each year were broadly similar, although some changes in the nutrition regime were implemented over the years of study. The nutrition prescriptions used in this nursery rely heavily on the use of tissue analyses, and steps are taken to correct any potential deficiencies as they arise. The target foliar concentrations are $1.4-2.2,0.1-0.4$ and $0.4-1.5 \%$ for $\mathrm{N}, \mathrm{P}$ and $K$, respectively. It is not possible to describe the exact nutrient regime used, but the most common regime in the final year of growth is to apply $14 \mathrm{~kg} \mathrm{~N} \mathrm{ha}^{-1}$ once a month from April to July. Potassium and magnesium are applied as necessary, by top dressings in June.

\subsection{Measurements and observations}

Physiological development of the plants was followed using a variety of techniques, but not all assessments were carried out in each year. A different sample of seedlings was used for each test.

\subsubsection{Shoot and root apical mitotic activity}

On most sampling occasions until March/April, the tips of terminal shoots and vigorous long-roots were removed for study from 15 randomly selected seedlings, fixed in $10 \%$ neutral formalin and stored in a refrigerator [9]. Before fixing, each shoot tip was dissected to remove the bud scales. At a later date, ten fixed shoot apices per lift date were excised from these tips, then squashed and stained to determine the percentage of dividing cells or mitotic index (MI), using a technique similar to that described by Grob and Owens [9]. Shoot apices were hydrolysed for about $45 \mathrm{~min}$ in $5 \mathrm{~N} \mathrm{HCl}$ and stained for 1-2 $\mathrm{h}$ in Schiff's reagent. After staining the fixed root tips in the same way, the apical meristem was 
prepared by 'peeling' off the root cap and some epidermal cells with the aid of tweezers, then excising the more deeply stained root apex from other tissue. As for shoot apices, ten fixed root apices per lift date were excised and squashed to determine MI. Sampling was performed by sequentially scanning and counting all mitotic figures under a compound microscope at a magnification of $\times 400$. Sampling was aided by the use of a $10 \times 10 \mathrm{~mm}$ ocular micrometer with divisions at $1 \mathrm{~mm}$. Cell counts were carried out in a similar manner at a magnification of $\times 100$.

\subsubsection{Cold hardiness}

On each sampling occasion, 15 first-order lateral shoots (10-15 cm long, $2-4 \mathrm{~mm}$ base diameter) from the current year's growth were subjected to one of a series of three to five minimum freezing temperatures in the range -3 to $-21{ }^{\circ} \mathrm{C}(1992 / 1993)$ or -3 to $-35{ }^{\circ} \mathrm{C}(1993 / 1994$, $1994 / 1995$ ) in a programmable freezer. The freezer first used in 1993/1994 had a lower limit than the one used in 1992/1993. Cold hardiness assessments were not made in $1991 / 1992$. The freezer cooled the air from $5{ }^{\circ} \mathrm{C}$ at $5{ }^{\circ} \mathrm{C} \mathrm{h}^{-1}$ until the desired minimum temperature was reached [4]. The shoots were held at the minimum temperature for $3 \mathrm{~h}$ and then warmed at $10{ }^{\circ} \mathrm{C} \mathrm{h}^{-1}$ to the holding temperature of $5{ }^{\circ} \mathrm{C}$. After freezing, the shoots were placed in beakers containing tap water and held in a heated $\left(18-23{ }^{\circ} \mathrm{C}\right.$ day $/ 15-18{ }^{\circ} \mathrm{C}$ night $)$ greenhouse for 2 weeks. Cold hardiness was determined by the extent of damage of needle tissue. Needle damage was scored [4]: 0 , no damage; $1,<50 \%$ of needles killed; $2,>50 \%$ killed but less than $100 \%$ killed; 3 , all needles dead. The temperature at which $50 \%$ of the needles $\left(\mathrm{LT}_{50}\right)$ died was interpolated from these data, assuming that these scores represented $0,33,66$ and $100 \%$ damage, respectively.

\subsection{Cold storage treatments}

Cold storage treatments were applied in 1993/1994 and 1994/1995 only. Because Douglas fir is considered to be very sensitive to cold storage [19], seedlings were lifted to the store on only four occasions between November and January each year. The stock was placed in co-extruded polyurethane bags and stored at $1-2{ }^{\circ} \mathrm{C}$. Seedlings from each lift date were removed from the store for study in early June (various durations of storage depending on lift date). The field performance of the seedlings was evaluated following storage.

\subsection{Field performance}

At approximately 4-5 week intervals in 1992/1993, 1993/1994 and 1994/1995, coinciding with every second test occasion above, an additional 100 seedlings were dispatched for field planting at the Tree Improvement Centre, Kilmacurra, Co. Wicklow (lat. 52 ${ }^{\circ} 56^{\prime} \mathrm{N}$, long. $6^{\circ} 09^{\prime} \mathrm{W}, 120 \mathrm{~m}$ elevation). The soil characteristics are: $\mathrm{pH} 5.7,7 \%$ organic matter, and sand, silt and clay fractions of 40,32 and $27 \%$, respectively.

The trial was laid out as a randomised block (3), splitplot design. Lifting date was the main plot and storage (freshly lifted and cold stored until June) was the (split) subplot. Each of the three blocks contained one replicate of each of the lifting date by treatment combinations, as a row plot of 30 seedlings. Spacing was approximately $50 \mathrm{~cm}$ between rows and $30 \mathrm{~cm}$ within rows.

Survival per subplot, initial height, height increment and lammas growth increment were recorded at the end of the first growing season of each year only. Because there was some variation in initial planting stock size, the height increment data were analysed as percentage of initial height. Subplot means were used in all data analyses.

\subsection{Meteorological data}

Because dormancy, cold hardiness development and growth are heavily influenced by weather conditions [12], air temperature and rainfall data were obtained from the weather station in Oakpark, Co. Carlow, approximately $18 \mathrm{~km}$ from Ballintemple nursery (figure 1). Unfortunately, similar data were not available for the nursery itself. Complete weather data for the planting site were not available either. Comparison of partial data for Kilmacurra with data for Oakpark (50 km apart) showed small differences in temperatures and rainfall.

\subsection{Data analysis and presentation}

Because the exact time of sampling varied from year to year, comparison of calendar date effects on response data were difficult to carry out. Therefore, the least significant differences of the means $(P<0.05)$ are presented in most cases. The standard errors are also presented for the height increment data, but to maintain clarity of presentation they are not shown in other cases. For the mitotic index data, dates having a high frequency of zeros (mainly in the case of shoot apices) were excluded from the tests. 


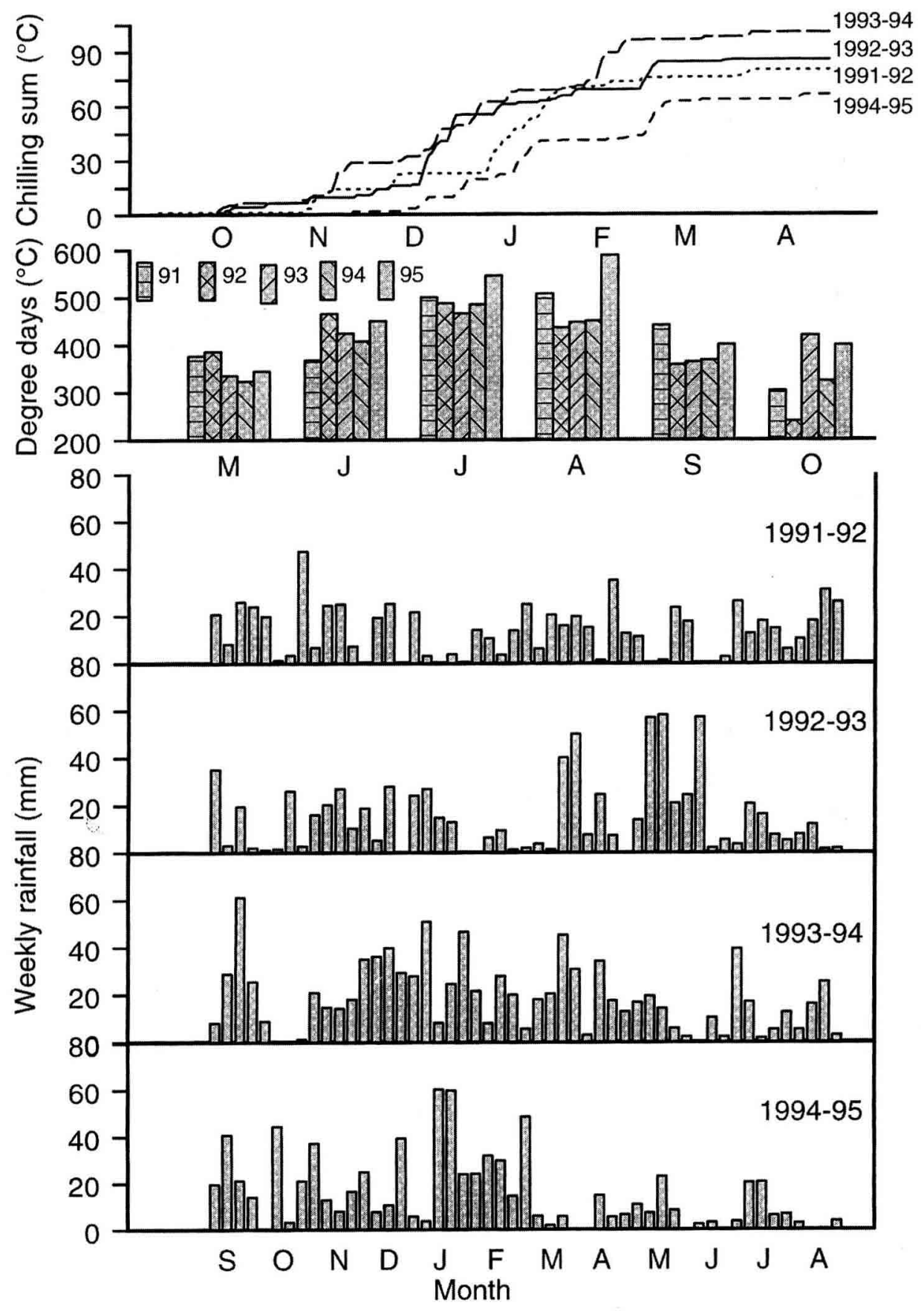

Figure 1. Accumulated daily chilling sums $\left(<5{ }^{\circ} \mathrm{C}\right)$ from 1 September to 30 April during the lifting season, monthly accumulated degree day sums $\left(>5^{\circ} \mathrm{C}\right)$ from May to October each year (1991 to 1995 , L to R) and weekly rainfall $(\mathrm{mm})$ for Oakpark, Co. Carlow, Ireland. (The station is $18 \mathrm{~km}$ from the nursery and $50 \mathrm{~km}$ from the field trial.)
To compare cold hardiness levels between 1993/1994 and 1994/1995, linear functions (other non-linear functions did not improve the fit) were fitted to the $\mathrm{LT}_{50}$ data for each year. Because few data were available for $1992 / 1993$, and the trend in cold hardiness development was almost identical to that of $1993 / 1994$, these data were not analysed. Separate functions were fitted to the acclimation or hardening phase (September/October to December), and deacclimation or dehardening phase (January to March/April). The slopes and intercepts of 
the lines for the acclimation and deacclimation phases of each year were compared using the GLM procedure in SAS [29].

The survival (after arc sine square root transformation) and percentage height increment data for each year were subjected to an ANOVA [29] to test for block and lift date separately for each treatment (freshly lifted/cold stored). Means for each lift date within each treatment were compared using Duncan's multiple range test. The performance of cold stored stock was compared with that of the freshly planted stock of same lift date using a $t$ test.

\section{Results}

\subsection{Physiology}

\subsubsection{Shoot mitotic index}

Although the general pattern of shoot apical activity in Douglas fir was similar each year, there were some differences among years (figure 2). Shoot MI was highest in November in 1991/1992 and 1992/1993, and lowest at this time the following 2 years. The apices became inactive in mid November, 1993/1994, the coolest year, and in early December in the other years. Resumption of activity occurred in early to mid March each year.

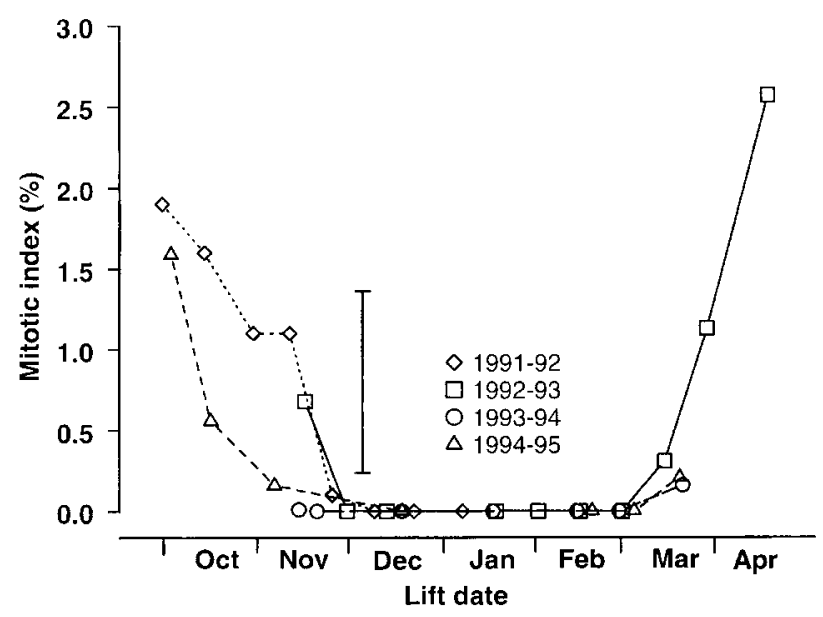

Figure 2. Shoot mitotic index of Douglas fir seedlings at time of lifting in the nursery. The vertical bar indicates the $5 \%$ LSD of the means.

\subsubsection{Root mitotic index}

The pattern of root MI was almost identical in 1991/1992 and 1992/1993, although fewer data points are available for the former year (figure 3). The root apices were highly active throughout the winters of both years. In 1992/1993, for example, root MI was relatively low from November to early December (1-3\%), then increased to a maximum in January to early March (4-6\%). MI declined in mid March (1-2\%) and increased again in April. Apices became inactive by mid November in 1993/1994 and early January in the milder 1994/1995 lifting season. MI generally increased rapidly in February of these years. MI declined again in late March 1994/1995.

\subsubsection{Shoot cold hardiness}

The pattern of cold hardiness development in Douglas fir was almost identical in 1992/1993 and 1993/1994, although no data are available for cold hardiness below $-21{ }^{\circ} \mathrm{C}$ in $1992 / 1993$ (figure 4). Cold hardiness $\left(\mathrm{LT}_{50}\right)$ increased from about $-8{ }^{\circ} \mathrm{C}$ in late September or early October to about $-20{ }^{\circ} \mathrm{C}$ in early November of these 2 years. In 1993/1994, cold hardiness increased more slowly after this time, reaching a maximum hardiness of about $-31{ }^{\circ} \mathrm{C}$ in mid January. Thereafter, the shoots dehardened gradually and reached $-25{ }^{\circ} \mathrm{C}$ by mid February. After this date, hardiness levels changed rapidly until mid March when it reached $-13{ }^{\circ} \mathrm{C}$. The shoots dehardened slowly after this point, reaching about $-6{ }^{\circ} \mathrm{C}$ in April.

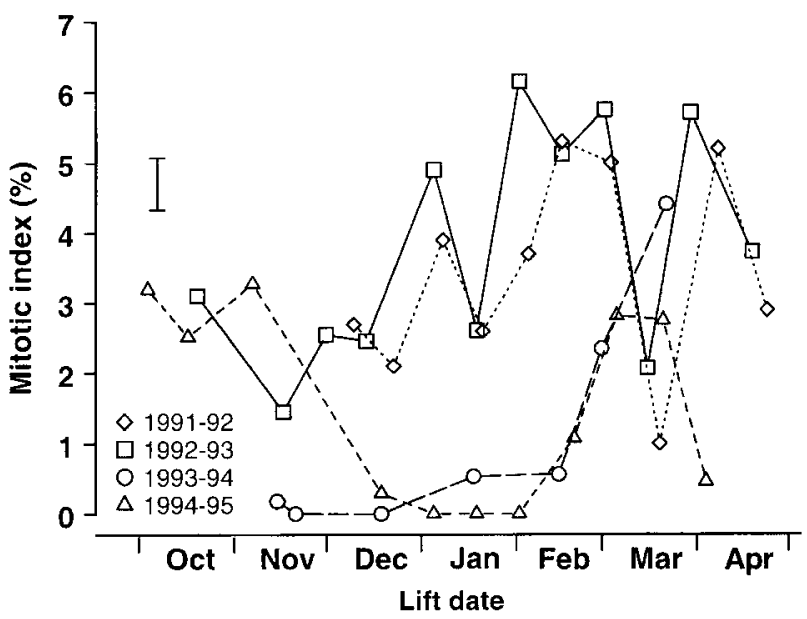

Figure 3. Root mitotic index of Douglas fir seedlings at time of lifting in the nursery. The vertical bar indicates the $5 \%$ LSD of the means. 


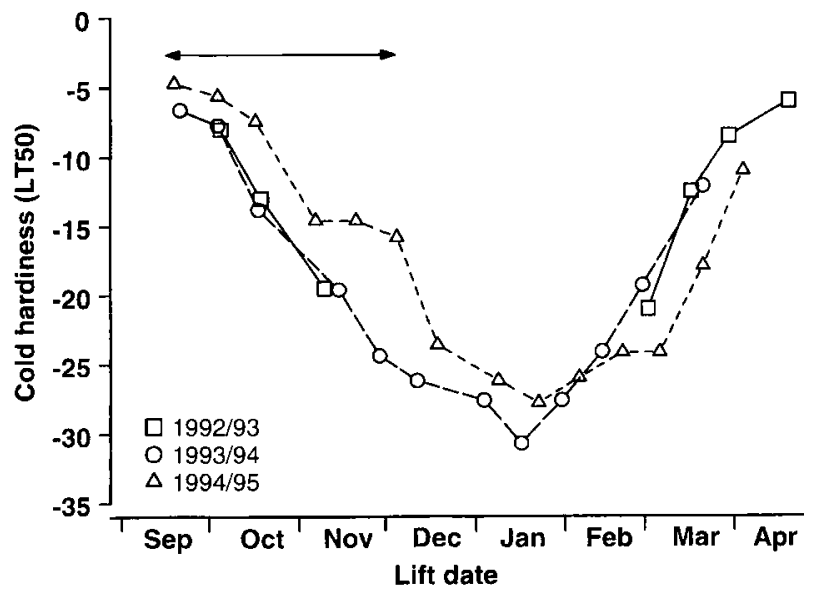

Figure 4. Cold hardiness levels of Douglas fir seedlings at time of lifting. Cold hardiness is based upon the temperature resulting in damage to $50 \%$ of the needles $\left(\mathrm{LT}_{50}\right)$. The slopes of the lines for 1993/1994 and 1994/1995 differed significantly $(P<0.05)$ from each other over period indicated by arrows. Differences between years were not significant at other times.

Cold hardiness developed significantly more slowly from September to December in $1994 / 1995$ than in $1993 / 1994(P<0.05)$ (figure 4$)$. Shoots were nearly $10{ }^{\circ} \mathrm{C}$ more hardy in November $1994 / 1995$ than in 1993/1994. During January and February, there were small differences between years. Deacclimation occurred a little later in 1994/1995 than in other years, although the magnitude of the differences was small and not significant.

\subsection{Field performance}

\subsubsection{Freshly planted stock}

Survival of seedlings planted soon after lifting was generally excellent (table I). Survival was greater than $95 \%$ for most planting dates in most years. However, survival was significantly lower for stock planted in January 1994 (81 \%), and in May 1995 (71 \%).

The height increment of freshly planted stock varied somewhat from year to year (figure 5). The effect of planting date on percentage height increment was highly significant for each year $(P<0.001)$, the best increment being achieved by those planted early in the season, especially for 1992/1993. A slight increase in height increment occurred for seedlings planted between late February and early March. Growth rates were more variable at each planting date in 1992/1993.

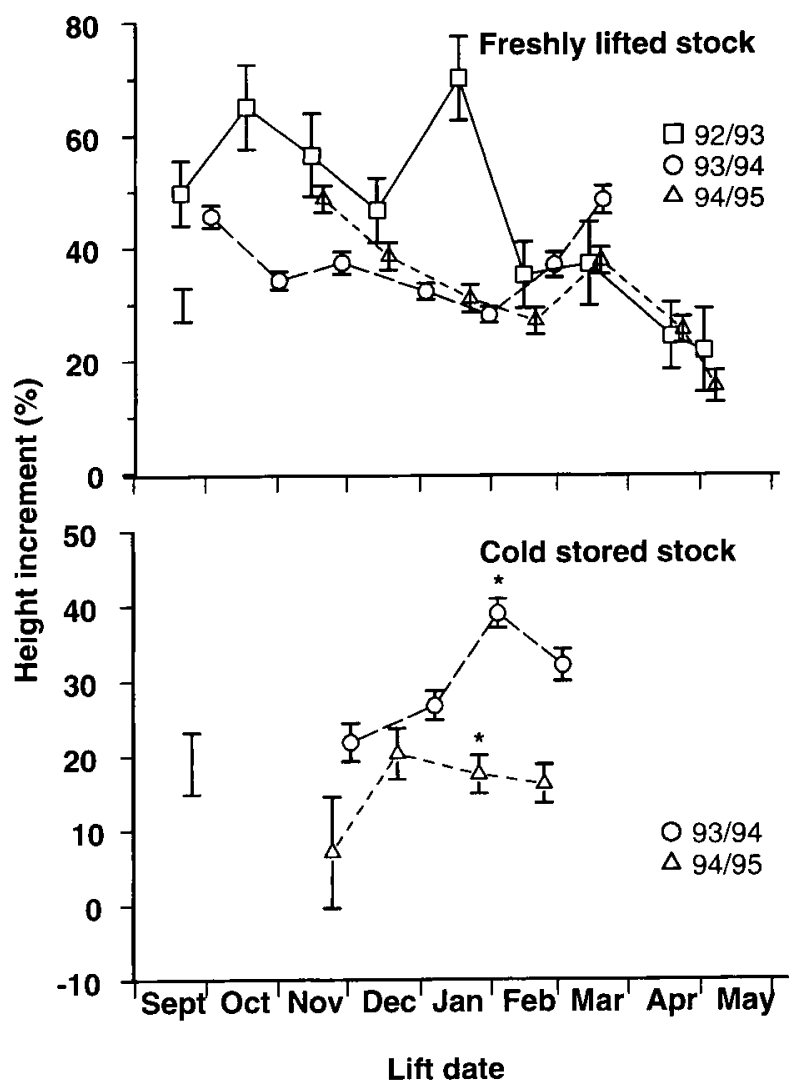

Figure 5. Height increment after one growing season as a percentage of initial height of Douglas fir seedlings planted soon after lifting or following cold storage and planting in early June. Vertical bars on symbols indicate standard errors, while the vertical line indicates the $5 \%$ LSD of the means. The means of the cold stored stock indicated $(*)$ are significantly different from the freshly planted stock of same lift date. Most of the cold stored seedlings from the November lift and many of those from the December lift in 1994/1995 died (table I).

Lammas growth in 1993 was also frequently observed in stock planted early in the planting season of 1992/1993, but few plants produced lammas shoots in other years. About $60-70 \%$ of the seedlings had lammas growth, and it accounted for as much as $33 \%$ of the total height increment. The frequency of lammas growth varied significantly among planting dates $(P<0.01)$, and was most frequent in seedlings planted from October to January.

\subsubsection{Cold stored stock}

For the seedling lifted in 1993/1994, the survival of stock cold stored to June 1994 was very good, varying from a low of $88 \%$ for the February lift to about $97 \%$ for those lifted in late January (differences not signifi- 
Table I. Survival ( \%) at the end of the growing season for Douglas fir seedlings, either freshly planted or cold stored and planted in early June.

\begin{tabular}{|c|c|c|c|c|c|c|c|}
\hline \multicolumn{2}{|c|}{$1992 / 1993$} & \multicolumn{3}{|c|}{$1993 / 1994$} & \multicolumn{3}{|c|}{$1994 / 1995$} \\
\hline Lift date & Freshly lifted & Lift date & Freshly lifted & Cold stored & Lift date & Freshly lifted & Cold stored \\
\hline 19 Oct. & $100^{\mathrm{a}}$ & 4 Oct. & $100^{\mathrm{a}}$ & & & 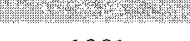 & \\
\hline 16 Nov. & $100^{\mathrm{a}}$ & 2 Nov. & $99^{a}$ & . & 21 Nov. & $100^{\mathrm{a}}$ & $12^{\mathrm{c}^{*}}$ \\
\hline 14 Dec. & $100^{a}$ & 29 Nov. & $97^{\mathrm{a}}$ & $93^{a}$ & 19 Dec. & $100^{\mathrm{a}}$ & $56^{\mathrm{b}^{*}}$ \\
\hline $15 \mathrm{Mar}$. & $100^{a}$ & 28 Feb. & $98^{\mathrm{a}}$ & $88^{\mathrm{a}}$ & 20 Mar. & $100^{\mathrm{a}}$ & ras \\
\hline 19 Apr. & $99^{a}$ & 21 Mar. & $98^{a}$ & & 24 Apr. & $100^{\mathrm{a}}$ & \\
\hline 3 May & $98^{a}$ & 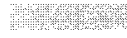 & IOA & & 8 May. & $71^{b}$ & \\
\hline
\end{tabular}

Means of each treatment type (e.g. freshly lifted, cold stored) followed by the same letter are not significantly different using Duncan's Multiple Range test. Cold storage lift dates values indicated $\left(^{*}\right)$ are significantly different from the freshly lifted stock of that date $(t$-test, at $5 \%$ level). Plants were not lifted and/or stored on dates indicated by shading.

cant) (table I). For the 1994/1995 stock, seedlings from the two first lifting dates had poor survival (12 and $56 \%$, in November and December, respectively), while those lifted in January and February had nearly $100 \%$ survival. Rainfall in the month of planting (June) in 1995 was very low and temperatures were high (figure 1).

The height increment of cold stored stock (figure 5) was greater for those planted in 1994 than for those planted in the warmer, drier season of 1995 (figure 1). For those planted in 1994, the best growth was achieved by seedlings lifted in late January and February 1994. The height increment of stock cold stored in January was significantly better than that achieved by the freshly planted stock of same lift date $(P<0.01)$, but not for other lift dates. For seedlings planted in 1995, the height increment of stock cold stored in January was lower $(P<0.01)$ than that achieved by the freshly planted stock of same lift date, but there was no significant difference for seedlings lifted in February. Survival was poor for the earlier lift dates of $1994 / 1995$, so height increment comparisons may not be meaningful.

When both survival and height increment percentage are considered, only those lifted to the store in January, and February to a slightly lesser extent, performed well both years, even if growth decreased for the January lift in 1995 (table I; figure 6). The drought and high temperatures that occurred in 1995 (figure 1) must be taken into consideration when evaluating the performance of the 1994/1995 stock.

\section{Discussion}

There are two main aspects to the results of the study. First, information is provided on the physiological status of Douglas fir seedlings during the period spanning the lifting season. Second, the association between physiological status and the field performance of freshly lifted and cold stored plants is examined. However, no attempt is made to predict field performance using physiological parameters. Provenance differences among years were unlikely to be a major factor in explaining response differences. For example, provenances from the same seed zone were used in 1992/1993 and 1994/1995, but the physiological responses of the seedlings differed between years.

\subsection{Physiological status of seedlings at lifting}

No clear relationship was found between the development of cold hardiness from September/October to December (figure 4) and shoot mitotic index (figure 2). The seedlings were considerably less cold hardy in the relatively warm year of 1994/1995 than in the cool years of 1992/1993 and 1993/1994. However, the MI data did not appear to follow the same trend. For example, shoot MI was lower in October/November 1994/1995 than in 1991/1992 (figure 2), but the former year was warmer than the latter year at this time (figure 1). Nevertheless, shoot apices became inactive earliest in the coldest year (1993/1994). Perhaps these results underline the fact that although cold hardiness and shoot MI may change in response to similar environmental stimuli, the pattern of change can not be expected to be identical. Similar results have been reported by Burr [2] and Cannell et al. [4]. Colombo et al. [5] found a very close relationship between shoot MI and the early stages of cold hardiness development in Picea mariana (Mill) B.S.P. growing in Ontario, Canada. 
Cold hardiness of shoots increased from $-4{ }^{\circ} \mathrm{C}$ in September to about $-15{ }^{\circ} \mathrm{C}$ in October 1994 , but increased little from November to early December that year (figure 4). Burr et al. [3] found that the early stages of cold hardiness development in Douglas fir were influenced primarily by photoperiod, but further hardening required low temperatures. There was little chilling until December in 1994 (figure 1), consistent with this interpretation. In contrast in 1993, there was a continuous accumulation of chilling from October onward, and chilling temperatures accumulated rapidly in November; cold hardiness also developed more rapidly in 1993.

The pattern of early cold hardiness development in the cool years of 1992/1993 and 1993/1994 (figure 4) was similar to that reported for Douglas fir growing in Scotland [4]. However, maximum hardiness levels were achieved earlier in Scotland, and high levels of hardiness were maintained until early March. In Ireland dehardening began slowly in early February. In the mild lifting season of 1994/1995, seedlings were less cold hardy than in other years. Cold hardiness also developed late in Douglas fir in a very mild season in another study carried out in Britain [19]. Cold hardiness levels appear to be heavily influenced by climatic factors, so the pattern of cold hardiness development can be expected to vary from year to year.

Cold hardiness development followed the clearest seasonal pattern over the 3 year period (1992-1995), and this may be the most useful parameter for describing the physiological status of Douglas fir growing in Ireland (see below). Cold hardiness is routinely used in the monitoring of the physiological status of seedlings [24]. High cold hardiness levels are generally associated with good stress resistance levels [2, 27].

The physiological measurements showed that the shoot system had a clear annual cycle of dormancy development. However, the roots of the seedlings were mitotically highly active throughout the winter in the first 2 years of observation. In fact, mean root MI was higher in the colder period of January and February, than in the warmer October to December period. The reason for this high MI is difficult to explain. Nevertheless, root growth potential of seedlings in a warm controlled environment often increases at this time of the year [28], and perhaps root MI can respond in a similar manner in the nursery provided that ambient environmental conditions are not limiting. In the final 2 years of the study, the roots had a very low MI or were inactive in December to January, but MI increased in February. Changes in nursery practices during the study period may have influenced the differences among years. In general, root MI declined again in March / April, coinciding with the time that shoot growth resumes. A similar decline has been noted at this time in Sitka spruce [22]. McKay and Mason [19] also noted high root MI during the winter months in Douglas fir, with a rapid rise in activity occurring in January. Winter root activity may have implications for the storability of Douglas fir [19], and this issue is discussed separately below.

\subsection{Physiological status and field performance}

The field performance of Douglas fir seedlings planted on various dates over several seasons in this farmfield trial probably reflected the biological potential of the seedlings on this site. The term 'biological potential' is used because all seedlings were handled with great care after lifting and/or after removal from the cold store, and planted soon after. Under forestry operational conditions in Ireland, this potential may not be realised because the plants may be handled differently. For example, it is not uncommon for seedlings to remain in temporary storage for some weeks before planting and post-planting conditions (e.g. weed competition) may be more stressful. Some of the other stresses that can occur during handling include desiccation, rough handling, high or low temperatures and lack of light $[16,20]$. In this study, planting dates that resulted in good field performance in the farm-field trial are recommended, but only if the dormancy status/stress resistance levels were relatively high as indicated by the physiological data.

\subsubsection{Freshly lifted stock}

Survival of seedlings planted from all planting dates was extremely good ( $>90 \%$ most dates), with two exceptions: planting in January 1994 and in May 1995. The low survival of the January stock may be a result of the low soil temperatures being unfavourable for root growth [17, 31, 32], or due to damage to the roots during lifting under wet conditions. The seedlings planted in May probably had low survival because they were lifted when stress resistance levels were very low (as indicated by cold hardiness levels), and probably also because of the dry, warm weather that occurred after planting that year (figure 1). The best height increment was generally achieved by seedlings planted from October until December/January. Lammas growth was a major contributing factor to this for those planted in 1992/1993. In studies conducted in the North York Moors in Britain $[17,18]$, there was no clear relationship between planting date and early height growth for freshly planted Douglas fir seedlings, but survival was better for those planted in the spring in another study [18]. Other studies conducted on Douglas fir in North America found no relationship between field performance and planting date 
[35] or found that those planted in December/January performed best $[6,26]$.

The generally good performance of seedlings planted early in the lifting season may be due to three factors. First, the root growth potential of the stock was relatively high (unpublished results), and second, soil temperatures were probably more favourable for root growth $[17,31,32]$. Third, root growth in Douglas fir is thought to be highly dependent on the availability of current photosynthate [23], and light intensity levels would be more favourable for this process in October and early November than in late November to January.

The period of high stress resistance when lifting and handling of planting stock is recommended is usually characterised by a period of low mitotic activity, and high cold hardiness levels [2], which is from November to February for Douglas fir in this study (figures 2-4). However, when field conditions are also considered, only the November to December period may be suitable for planting this species under operational conditions in Ireland. Planting in October may also be possible, but only if the seedlings are planted within 2-4 days of lifting, as occurred here. Similarly, Tabbush [32] recommended planting of Douglas fir in October and November in the warmer areas of Britain. The temperatures of the soil in many forest sites in January and February may not be favourable for root growth and absorption of water $[17,32]$. Such seedlings may deteriorate slowly owing to the loss of moisture during transpiration. In addition, Douglas fir roots cannot tolerate frosts under $-4^{\circ} \mathrm{C}$ [15], so the risk of frost damage between the time of lifting and field planting is higher also.

\subsubsection{Cold stored stock}

The results of this study indicate that long-term cold storage of Douglas fir is viable, but the window of opportunity for placing the plants in storage is narrow. Field performance was best for those placed in store in January and February of both years. Seedlings from the November and December lift dates did better in $1993 / 1994$ than in 1994/1995, probably because they were at a more advanced stage of dormancy/stress resistance development at these times in 1993/1994 (figures 2-4). Cold hardiness levels may be a good indicator of stress resistance levels [2], and the seedlings stored well when shoot cold hardiness levels exceeded $-20^{\circ} \mathrm{C}$.

Although stock cold stored from January or February until June performed well in the field, a shorter period of storage may be desirable. The duration of the growing season is short for those planted in June, and the risk of drought stress following planting is higher. Furthermore, a shorter period of storage (perhaps until April) would probably widen the lifting window. McKay and Howes [18] make a similar recommendation for Douglas fir growing in Britain.

In Douglas fir grown in northern Britain, Cannell et al. [4], McKay and Mason [19] and McKay [14] found that seedlings deteriorated quickly in cold storage, while others $[30,31]$ found some evidence that cold storage may be possible. Douglas fir is routinely cold or freezer stored in North America and France $[1,7,8,10,11,25$, 33, 34, 35]. McKay and Mason [18] suggest that Douglas fir may be difficult to store perhaps because i) its roots remain active in the winter, and/or ii) cultural practices in the nursery encourage late season activity. The seedlings used in this study were from an operational nursery, and the nursery has been implementing small changes in the nutritional regimes (B. Thompson, per. comm.). Root MI reached zero in the very mild winter of 1994/1995, while they remained active in the cooler seasons of previous years, perhaps partly in response to the new nutritional regimes. This may be the reason why Douglas fir was successfully cold stored. Cold storage treatments were carried out only in the last 2 years of study, so the hypothesis presented by McKay and Mason [19] can not be refuted. Nevertheless, Douglas fir seedlings lifted from another nursery in Ireland have been successfully cold stored during two subsequent lifting seasons (unpublished results). Furthermore, recent research results from Britain [18] suggest that Douglas fir can be stored until April when lifted to the store from mid January to mid March. Such results can be applied also in Ireland.

Acknowledgements: The authors would like to thank the following for their assistance in carrying out this work: N. Morrissey, G. DeBrit and B. Thompson. Special thanks to J. Kilbride who supervised most of the lifting operations. Financial assistance was provided by Coillte Teo. (Irish Forestry Board), Forbairt (Irish National Science Agency), the EU AIR Programme (contract no. CT 920143) and COFORD (Council for Forest Research and Development). B. Généré (Cemagref, Nogent-Sur-Vernisson, France) translated the summary. The input of two anonymous referees to improving the paper is appreciated.

\section{References}

[1] Burdett A.N., Simpson D.G., Lifting, grading, packaging, and storing, in: Duryea M.L., Landis T.D. (Eds.), Forest Nursery Manual: Production of Bareroot Seedlings, Martinus Nijhoff/Dr W Junk Publ, The Hague/Boston/Lancaster, 1984, pp. 227-234.

[2] Burr K.E., The target seedling concepts: bud dormancy and cold hardiness, US DA, For. Serv. Gen. Tech. Rep. RM200, 1990, pp. 79-90. 
[3] Burr K.A., Tinus R.W., Wallner S.J., King R.M., Relationships among cold hardiness, root growth potential and bud dormancy in three conifers, Tree Physiol. 5 (1989) 291-306.

[4] Cannell M.G.R., Tabbush P.M., Deans J.D., Hollingsworth M.K., Sheppard L.J., Philipson J.J., Murray M.B., Sitka spruce and Douglas fir seedlings in the nursery and in cold storage: root growth potential, carbohydrate content, dormancy, frost hardiness and mitotic index, Forestry 63 (1990) 9-27.

[5] Colombo S.J., Glerum C., Webb D.P., Winter hardening in first-year black spruce (Picea mariana) seedlings, Physiol. Plant. 76 (1989) $1-9$.

[6] Dunsworth B.G., Impact of lift date and storage on field performance for Douglas fir and western hemlock, USDA Gen. Tech. Rep. RM-167, 1988, pp. 199-206.

[7] Garriou D., Généré B., La crise de transplantation du Douglas en fonction de trois facteurs de variation, Forêt-entreprise, No 103, 1995, pp. 56-60.

[8] Godreau V., Effet du stockage au froid de plants forestiers sur leur potentiel de régénération racinaire et quelques paramètres physiologiques: réserves glucidiques, état hydrique et échanges gazeux foliares, DEA, université de Nancy I, 1989, pp. 41.

[9] Grob J.A., Owens J.N., Techniques to study the cell cycle in conifer shoot apical meristems, Can. J. For. Res. 24 (1994) 472-482.

[10] Hermann R.K., Seasonal variation in sensitivity of Douglas fir seedlings to exposure of roots, For. Sci. 13 (1967) 140-149.

[11] Jenkinson J.L., Nelson J.A., Cold storage increases dehydration stress in pacific Douglas fir, USDA, For. Serv Gen. Tech. Rep. INT-185, 1984, pp. 38-44.

[12] Lavender D.P., Plant physiology and nursery environment: interactions affecting seedling growth, in: Duryea M.L., Landis T.D. (Eds.), Forest Nursery Manual: Production of Bareroot Seedlings, Martinus Nijhoff/Dr W. Junk Publ., The Hague/Boston/Lancaster, 1984, pp. 133-141.

[13] Mason W.L., Sharpe A.L., Deans J.D., Growing regimes for bare-root stock of Sitka spruce, Douglas fir and Scots pine II. Forest performance, Forestry (suppl.) 62 (1989) 275-284.

[14] McKay H.M., Tolerance of conifer fine roots to cold storage, Can. J. For. Res. 23 (1993) 237-342.

[15] McKay H.M., Frost hardiness and cold storage tolerance of the root system of Picea sitchensis, Pseudotsuga menziesii, Larix kaempferi and Pinus sylvestris bare-root seedlings, Scand. J. For. Res. 9 (1994) 203-213.

[16] McKay H.M., A review of the effect of stresses between lifting and planting on nursery stock quality and performance, New Forests 13 (1997) 369-399.

[17] McKay H.M., Optimal planting times for freshly lifted bare-rooted conifers on the North York Moors, Forestry 71 (1998) 33-48.

[18] McKay H.M., Howes R., Recommended plant type and lifting dates for direct planting and cold storage of bare-root
Douglas fir in Britain, For. Comm. Res. Inf. Note 284, 1996, $5 \mathrm{pp}$.

[19] McKay H.M., Mason W.L., Physiological indicators of tolerance to cold storage in Sitka spruce and Douglas fir, Can. J. For. Res. 21 (1991) 890-901.

[20] McKay H.M., White M.S., Fine root electrolyte leakage and moisture content: indices of Sitka spruce and Douglas fir seedling performance after desiccation, New For. 13 (1997) 139-162.

[21] McKay H.M., Aldhous J.R., Mason W.L., Lifting, storage, handling and dispatch, in: Aldhous J.R., Mason W.L. (Eds.), Forest Nursery Practice, British Forestry Commission, Bull. 111, 1994, pp. 198-222.

[22] O'Reilly C., Keane M., Root wrenching may influence dormancy development of Sitka spruce in the nursery, Ir. For. 53 (1996) 45-54.

[23] Philipson J.J., Root growth in Sitka spruce and Douglas fir transplants: dependence on the shoot and stored carbohydrate, Tree Physiol. 4 (1988) 101-108.

[24] Ritchie G.A., Assessing seedling quality, in: Duryea M.L., Landis T.D. (Eds.), Forest Nursery Manual: Production of Bareroot Seedlings, Martinus Nijhoff/Dr W. Junk Publ., The Hague/Boston/Lancaster, 1984, pp. 243-249.

[25] Ritchie G.A., Effect of freezer storage on bud dormancy release in Douglas fir seedlings, Can. J. For. Res. 14 (1984) $186-190$.

[26] Ritchie G.A., Relationship among bud dormancy status, cold hardiness, and stress resistance in $2+0$ Douglas fir, New For. 1 (1986) 29-42.

[27] Ritchie G.A., Integrated growing schedules for achieving physiological uniformity in planting stock, Forestry (suppl) 62 (1989) 213-227.

[28] Ritchie G.A., Dunlap J.R., Root growth potential: its development and expression in forest tree seedlings, N. Z. J. Forestry Sci. 10 (1980) 218-248.

[29] SAS Institute Inc., SAS/STAR ${ }^{(1)}$ User's guide, Version 6, Volume 1, Cary, NC: SAS Institute Inc., Cary, NC, USA, $1989,943 \mathrm{pp}$.

[30] Sharpe A.L., Mason W.L., Some methods of cold storage can seriously affect root growth potential and root moisture content and subsequent forest performance of Sitka spruce and Douglas fir transplants, Forestry 65 (1992) 463-472.

[31] Sharpe A.L., Mason W.L., Howes R.E.J., Early forest performance of roughly handled Sitka spruce and Douglas fir of different plant types, Scott. For. 44 (1990) 257-265.

[32] Tabbush P.M., Silvicultural systems for upland restocking, Br. For. Comm. Bull. 76, 1988, 21 pp.

[33] Tung C.H., Wisniewski L., DeYoe D.R., Effects of prolonged cold storage on phenology and performance of Douglas fir and noble fir $2+0$ seedlings from high elevation sources, Can. J. For. Res. 16 (1986) 471-475.

[34] van den Driessche R., Survival of coastal and interior Douglas fir seedlings after storage at different temperatures, and effectiveness of cold storage in satisfying chilling requirements, Can. J. For. Res. 7 (1977) 125-131.

[35] Winjum J.K., Effects of lifting date and storage on 2-0 Douglas fir and noble fir, J. For. 61 (1963) 648-654. 